https://helda.helsinki.fi

\title{
'Learning' Development
}

\section{White, Pamela}

2018

White , P \& Devereux , P 2018 , ' 'Learning' Development ' , Forum for Development Studies , vol. 45 , no. 1 , pp. 119-141 . https://doi.org/10.1080/08039410.2017.1393458

http://hdl.handle.net/10138/232201

https://doi.org/10.1080/08039410.2017.1393458

cc_by_nd

Downloaded from Helda, University of Helsinki institutional repository.

This is an electronic reprint of the original article.

This reprint may differ from the original in pagination and typographic detail.

Please cite the original version. 


\section{'Learning' Development}

\section{Pamela White \& Peter Devereux}

To cite this article: Pamela White \& Peter Devereux (2018) 'Learning' Development, Forum for Development Studies, 45:1, 119-141, DOI: 10.1080/08039410.2017.1393458

To link to this article: https://doi.org/10.1080/08039410.2017.1393458

曲 Published online: 31 Oct 2017.

Submit your article to this journal $\pi$

山 Article views: 71

Q View related articles $\sqsubset$

View Crossmark data $־$ 


\title{
'Learning' Development
}

\author{
Pamela White $\mathbb{D}^{\mathrm{a}, \mathrm{b}}$ and Peter Devereux \\ ${ }^{a}$ Department of Social Sciences, University of Helsinki, Helsinki, Finland; ${ }^{b}$ FCG \\ International Ltd, Helsinki, Finland; ' Sustainability Policy Institute, Faculty of Humanities, \\ Curtin University, Perth, WA, Australia
}

\begin{abstract}
How can we prepare for and motivate ongoing improvements in development practice in the world of universal sustainable development goals? International Development Studies courses are a relatively new phenomenon. Earlier, people entered the field with technical backgrounds and learnt on the job. Similarly, many took the road from long-term international volunteering or Junior Expert/ Junior Professional Officer posts, and moved into a career in international development [Baillie Smith, M. and N. Laurie, 2011, 'International volunteering and development: Global citizenship and neoliberal professionalisation today', Transactions of the Institute of British Geographers; Devereux, P., 2008, 'International volunteering for development and sustainability: Outdated paternalism or a radical response to globalisation?', Development in Practice, Vol. 18, No. 3, pp. 357370; White, P., 2015, 'The spectrum of motivations, experiences and attitudes in technical development cooperation', Forum for Development Studies, Vol. 42, No. 1, pp. 89-112]. More recently, development studies courses have emerged. Are they finding the right balance between critical approaches, history and vocational skills? A difference in motivations and expectations between early and mid-late career Finnish development workers was found from earlier research (White, 2015). With this case study we add a focus on the pre-career stage (via questionnaires and interviews), considering the motivations of Finnish development studies students in first year, postgraduate studies and after graduation. The article acknowledges the range of motivations and experience of those engaged with international development. It also considers the tension between critical theory and vocational skills. Competencies for development practice encompass a combination of theoretical knowledge, technical skills, administrative knowhow and attitudinal factors. We conclude that co-production, combining academic courses and research, including reflective and experiential practice, is a positive step forward.
\end{abstract}

Keywords: motivation; development cooperation; development studies; development competencies; sustainable development goals 


\section{Introduction}

Many young persons in western countries aspire to work in development cooperation. What route do they take to achieve this goal? A broad selection of development studies courses has emerged in recent years, usually combining critical approaches, history and vocational skills to varying degrees. Should development studies be a tool to socialise young entrants for a career in development cooperation, and if so, what sort of training is appropriate? How can we prepare for and motivate ongoing improvements in development practice in the world of universal sustainable development goals (SDGs), which frame work abroad and at home, requiring more complex, inter and trans disciplinary understanding, partnerships and practice?

Earlier research (White, 2011; 2015; White et al., 2011) has focused on Finnish development professionals working in a range of categories, from volunteers, to NGOs, private sector consultants, government employees and staff of the multilateral organisations. White (2015) identified similar motivations and attitudes, no matter what type of job they held. However, it also indicated that there may be a generational difference, with younger persons entering the business demonstrating more of a career focus. Jones (2008) has suggested that the globalisation of work has encouraged young people (and their governments) to focus more on strengthening their cvs and practical problem solving skills in an international context. For example recent studies suggest that international volunteer placements may speed up the development of valuable global skills and capabilities (Fees and Gray, 2011).

The earlier work of White also demonstrated a variety of routes to enter development work. In the 1980s and earlier, most development workers came from technical/professional backgrounds, and then 'fell' into development work - either as volunteers or directly into technical roles (also Eyben, 2012; 2014). Many volunteers continue to go on to long-term work in development. 'Volunteering is a major source of relevant training for individuals planning a career in international development. One-third (31 per cent) of returned volunteers are now working in international development' (Office of Development Effectiveness, 2014, p. 1).

Later entrants tended to study with this career in mind. Unlike during the 1980s there are now academic pathways to development work, via many university courses in development studies. However, there are some critiques of what the role of development studies is? Should it focus on critical thinking on international development, or should there be more vocational training included, with the idea of skilling workready graduates (e.g. Denskus and Esser, 2015; Woolcock, 2007).

At the same time development praxis is changing. 2016 has ushered in the SDGs, applying equally to 'developing' and 'developed' countries, in the struggle to achieve social justice and basic human development, while staying within sustainable environmental limits. What are the skills that are needed now to achieve the SDGs, at home as well as in developing countries? 
There has not apparently been any study of motivations of development workers at the point of starting their studies. Do they start with the aim of 'saving the world'? How strongly do they self-identify with different categories of development worker? After some years of working life will they join the general development culture, with a blend of 'missionary' and 'mercenary' identities (as found by Fechter, 2012; Stirrat, 2008; White, 2015)? Or is this younger generation indeed different, identifying as a more professional, globalised corp which can respond flexibly to the changing development environment?

This article looks at motivations and pathways for working in international development and creating the space for motivating and achieving better development practice and practitioners. It investigates the motivations and attitudes of Finnish students of development studies, as well as alumni and their career paths: what has motivated them to choose the course of studies, their perceptions of the career and whether their motivations change during the course and after exposure to development work in the field. It also considers the role of development studies, and what competencies might be needed for development work. This research contributes to the very limited knowledge of those at the entry point to a career in development, testing their self-identification within an ill-defined profession. This part of ongoing $\mathrm{PhD}$ research on motivations and experiences of different roles of technical development cooperation.

\section{Literature}

\section{Technical development cooperation and development studies}

The Organisation for Economic Cooperation and Development/Development Assistance Committee (OECD/DAC) defines technical cooperation as 'the provision of know-how in the form of personnel ... this comprises activities financed by a donor country whose primary purpose is to augment the level of knowledge, skills, technical know-how or productive aptitudes of the population of developing countries'. This definition most commonly refers to consultants or technical staff in bilateral or multilateral programmes and projects or NGO-funded activities. However, it also includes volunteers 'under wholly or partly publicly financed or publicly controlled volunteer programmes, receiving a stipend in compensation for their services', as well as development researchers funded by the donor (OECD/DAC, 2010, p. 15). This definition of technical cooperation forms the basis for this study - a potential career that emerged in the second half of the twentieth century, and accelerated in the early twenty-first century with a multitude of ways to work and live in developing countries. Many professionals worldwide have established careers in international organisations such as the UN, the World Bank, International Monetary Fund and other regional and national development-focused institutions, as well as in NGOs and bilateral projects. 


\section{Motivations in development cooperation}

Earlier research has considered learning for sustainable development and what makes for good development practice. This has included research findings on volunteering for development and sustainability (Devereux, 2010; Haddock and Devereux, 2015), as well as experience of other types of development practitioners (Fechter, 2011; 2012; Stirrat, 2008; White, 2011; 2015).

We do not consider in this article the motivations to work in technical cooperation of young persons who originate from developing countries. Naturally these are also very important and relevant for study, particularly in the context of universal SDGs and emerging economies, but their motivations are potentially quite different. These are considered in another article under work by White. There is also a significant difference between development cooperation and humanitarian work, and the skills needed, with the latter more focused on emergencies, conflicts and immediate responses to crises.

Altruism is often seen to set development workers apart from other western professionals working outside their country (e.g. in military, diplomatic or business fields). Most of the practitioners interviewed in our earlier research (White and Devereux) identified altruism - the wish to 'do good' or 'make a difference' - as important, though not sole or primary motivators. However, White (2015) also identified a more fluid spectrum of roles, motivations and behaviours, as many development workers have worked in a range of roles, including research, volunteering and consultancy.

Clearly a good salary and career path could be a motivating factor. Fechter (2012) noted the critiques of aid work are partly about public discomfort with the idea that development workers can make a good career from poverty. She highlights this as a failure to consider the justified importance of care for self as well as care for others, which have been extensively discussed, for example, in nursing and social work. She argues

the absence of equivalent research in development studies is partly the result of a pervasive tendency to foreground the 'other' - the world's poor - while rendering those who deliver aid less visible. This is problematic insofar as it does not encourage critical examination of their motives, or of the challenges and benefits that result from their involvement. This does not mean that a potentially apolitical concern with the aid worker self should replace a concern for the other, but that they both need to be brought into view. (p. 1489)

Earlier research by White $(2011 ; 2015)$ noted that when surveying young, early career Finnish experts in bilateral and multilateral cooperation the most commonly expressed motivation (68 per cent) was to gain relevant professional experience that might facilitate a career in the development industry, with the UN or other organisations. Some junior experts noted that their primary interest was to gain knowledge and skills so that they would be able to take up positions as a consultant in development projects. Many had also worked in earlier volunteer posts or unpaid internships, hence it 
is natural that they wanted and needed to take the next step towards a career (although in practice many were frustrated by the difficulty of the next step). And their motivations were not black and white, with many expressing other interests. 'I expected getting a huge amount of experience, maybe a rewarding feeling of imagining that we were "doing good", and a lot of unforgettable memories.'

Stirrat (2008) discussed the stereotypes of those working in development (often self-applied) of mercenary, missionary and misfit. The 'mercenaries' were the development professionals working for donors or consulting companies. 'Missionaries' included volunteers or NGO workers, who he identified as having a vocation driven by a sense of duty, though also a stereotype of amateurism and ineffectiveness. He also suggested that these two categories are converging with time, as the NGOs become more professional and consulting companies more focused on the 'soft' aspects of development, rather than the earlier technical/infrastructure focus.

This takes us beyond a simplistic binary of those working in aid, with romantic notions of volunteers, versus the 'mercenary' practitioners of consulting companies or multilateral agencies. The reasons why young people go into development work as a student or volunteer may also leave room for less strategic considerations, such as: just looking for fun, something to do in a gap year, or being exposed to volunteer opportunities (Holdsworth, 2010). In development work a shift is required from what Wilson (2006, p. 517) calls 'instrumental, to more political learning ... characterised as moving from strategic "learning from/about" to transformational "learning with". He described the change in recent years in technical assistance, moving from a top down process to manage multi-stakeholder learning processes, requiring competences in collaboration, partnership formation and dialogue (Wilson, 2007). This process does not require experts (or presumably other actors) to set aside their specific expertise but to focus on 'learning with'.

\section{Motivations in other fields}

Research of motivations from other fields is also relevant, particularly to other 'caring' professions, such as teaching, nursing or social work. For instance, research on the motivations of school teachers (Watt and Richardson, 2008) identified a range of types of motivations. They broke these down to intrinsic value, referring to the enjoyment one gets from carrying out a given task; social utility value of how a task will be useful to an individual or society in the future, or making a social or altruistic contribution; and extrinsic or attainment value, which was considered to mean the subjective importance of doing well on the task, in terms of social status, morale and salary. These categories were used to classify students on the basis of their likelihood to choose a teaching course and to persist with the career after studies. These findings were used in development of the current article.

They noted that researchers had identified the main reason for choosing a teaching career was the intellectual fulfilment, along with the desire to make a social 
contribution. This was particularly so for mid-life career switchers into teaching, who did not identify salary and conditions as motivations - much like the older development worker respondents in the research of White (2015). Those participants who chose teaching for these reasons were also those most satisfied with their career choice. However, they also identified some students were motivated by the benefits of a steady salary and long holidays (which in some persons' eyes could be similar to the perception of high salary and glamour of development work). In addition, Watt and Richardson (2008) note a difference between the more altruistic, service-oriented goals of baby boomer generation teachers, and those of Generation $\mathrm{Y}$, who were more focused on salary and job security, due to the changed nature of work and employment prospects. This also was in line with the research of White (2015).

Simpson (2015) described the concept of socialisation in higher education - the way in which students adapt to their new career role and internally to their self-conceptualisation of that role (in her case referring to social work students). She summarised the ways this happens - one way involving the acquisition of values and attitudes, interests, skills and knowledge directly through didactic teaching in higher education, and indirectly through interaction with the profession. However, the other driving force is the motivation, identity and commitment of the student, with socialisation as a process whereby the student learns to adapt to the practice and organisational context. While development work is not a profession in itself, development studies students can benefit from didactic teaching and exposure to practical work and those already working in development (who often have a strong motivation and identity).

\section{Development studies, experiential learning, professionalisation and critical thinking?}

Development cooperation is an ill-defined profession - there is no clear set of competencies required. Traditionally there was no academic training as such for development work. Typically in the mid-1990s and earlier, people entered the field with technical backgrounds (particularly forestry, agriculture, engineering and health) and learnt on the job. In many cases, they learned 'soft' skills on the job and this turned into a lifetime in development practice.

The paths to a career in development nowadays are many. One option is to do temporary and low paid jobs or international volunteering in order to gain experience, even if career enhancement is not the only motivation. Brown $(2015$, p. 1) suggests that 'through opening spaces for dialogue and experiential learning, international volunteering, accompanied by critical development education, has the potential to address questions about what responsible development might mean, and how we can actively contribute to it'.

However, the increasing professionalisation of the development business is increasing the demands on all actors and leading to a more career-oriented attitude towards 
development work. In addition, decreasing funding for international development, fewer and shorter international posts and more focus on national experts, mean there are fewer opportunities for young westerners. Entering the field of development is becoming more difficult, just as interest peaks. Eyben (2012) notes this leaves very little room for young entrants. Just as the role of a development worker has become an acknowledged career, with specific training, it has become more difficult to take that path.

There is a blossoming of development studies courses in universities worldwide. Much of the discourse of development studies has focused on a critique of aid (often with good reason). So there is a dilemma that at the same time students may take the development studies path in the hope of a long-term career in development, sparked by growing discussion of development in social media, television, etc., yet what they learn makes them critical of how that path is trod.

Corbridge (2007) described the unusual nature of development studies

It is committed both to the principle of difference (the Third World is different, hence the need for a separate field of studies) and to the principle of similarity (it is the job of development policy to make 'them' more like 'us'). (p. 179)

He considers that this apparent contradiction is why development studies has been criticised by all sides, but argues that it still plays an important role.

In setting their curriculum, universities try to find the balance between the desires of students for theoretical grounding and practical skills for a career in development, while simultaneously trying to instil critical thinking. Is there a shared view of universities and students regarding what capacities are needed? Moreover, what do developing country communities or emerging economies want? To make this debate even more complicated, there is unlikely to be a single view on technical cooperation needs within even a single developing country, given the variation of stakeholders. Denskus and Esser (2015) critique the vocationalisation of development studies education, considering that spaces for critical reflection are abandoned in the increasing need for employability of graduates. One option could be to combine the academic and practical streams more closely via the experiential learning opportunities that long- and short-term volunteering can provide.

Akram-Lodhi (2016) describes the way that development studies courses reflected the debates of the day internationally, from modernisation to the Millennium Development Goals, and are beginning to turn more to a focus on global development, including in the west. Currie-Alder (2016, p. 6) goes back much further describing the history of development studies from more than two centuries identifying three traditions emphasising 'poor places abroad, progress at home and global interdependencies'. BaillieSmith (2013) highlights the importance of 'co-production of critical academic knowledges' between practice and research. Such co-production is important both in university courses preparing people for development work as well as for development 
practitioners in the field. It highlights the need for reflective development practice. This also reflects a shift in research from multidisciplinary (with researchers cooperating within their discipline) to interdisciplinary (where researchers cross disciplines) and now transdisciplinary approaches with cooperation between researchers and practitioners (Mobjork, 2010). Buch-Hansen and Lauridsen (2012, p. 299) note the particular importance of interdisciplinary development studies within the sustainable development context.

Woolcock (2007) describes Master's degree courses in development, for students coming from first degrees in other courses. He felt that

irrespective of a student's disciplinary orientation, regional specialization, or sectoral interests, three distinctive core competencies will be expected of him/her in the early years following graduation. I call these competencies the skills of the 'detective' (locating, generating, analysing, and interpreting information), the 'translator' (mediating a dialogue between very different constituencies - policymakers, managers, field staff, villagers, local officials, academics, donors), and the 'diplomat' (brokering differences, doing deals, moving agendas, negotiating agreements). (p. 57)

The University of Helsinki defines the discipline of Development Studies as follows:

The discipline of development studies examines development, poverty, inequality as well as social, political, environmental and cultural changes and continuities in the Global South from a multidisciplinary perspective. At the University of Helsinki, research in development studies concentrates on global political economics, globalisation and development, institutions and development policy, environmental management, natural resources policy, urban issues, justice and cultural diversity, religion and development, and alternative forms of development in the Global South.

Development studies has expanded at the University of Helsinki from being strictly centred on the developing countries to include diverse South-North relations in our globalising world. (https://www.helsinki.fi/en/faculty-of-social-sciences/research/ disciplines-and-research\#section-21998)

From this it is clear that the coverage is broad, and is also encompassing the Agenda 2030 issues.

On the other hand the University of Jyväskylä describes the learning outcomes of their interdisciplinary Masters in Development and International Cooperation, Specialisation in Development Studies, as being more focused on the tools and practical skills students will acquire - in other words, a more vocational focus, though in addition, some mentioned is made of critical analysis skills. Students are required to pursue an internship with a firm or organisation active in the area of international development, in order to gain practical experience (website - https://www.jyu.fi/ops/en/hytk/masters-degree-programme-indevelopment-and-international-cooperation-specialication-in-development-studies). 


\section{Methodology for survey of Finnish students, alumni and development workers}

The Finnish research is based on a heuristic study by White of three sub-groups of students and alumni, and of older development workers. White circulated an online survey to the students majoring in Development Studies (both those continuing through from $\mathrm{BSc}$ to MSc, and those entering only at the MSc stage, with a BSc in a different field) in the University of Helsinki (Survey 1), and those in the Master's level course in the University of Jyväskylä (having a BSc in another field) (Survey 2). The surveys were undertaken in late 2015. In addition, data were taken from an earlier (unpublished) survey of development studies alumni carried out by the University of Helsinki, Development Studies department (44 respondents, Survey 3). This survey was carried out in 2013, and mainly focused on the working life of alumni after graduation, their experiences of studying and employment, and their suggestions for improving the development studies course.

The three groups are relatively small - Helsinki's intake is 10 students annually to do their Bachelor's degree in Social Sciences, with a major in Development Studies (with most intending to continue to a MSc, though there are also students taking Development Studies courses as a minor within other streams) and additionally 8 to do their MSc only; and that of Jyväskylä is 15-25 students each year. A very small pool, but by using both universities, the $N$ is increased somewhat. It is also of interest to see whether there is a different perception and motivation of the students that study development studies from undergraduate level or only as a Masters course - though it is recognised that with the small numbers the comparison is not significant.

A web-based questionnaire was prepared and circulated on Google Drive, with questions of background, travel history, motivations, expectations from the course and from their working life, and general opinions about development. The questions were partly informed by the work of Watt and Richardson (2008) with teaching students, considering intrinsic, altruistic and extrinsic motivations.

As many students as possible were invited to participate via the student email network, following a short introduction of the research by email, and in two face-toface introductions in lectures. Two follow-up interviews were then held with recent graduates (one of whom had answered the survey) to deepen the findings, following a similar line of questioning as the survey. The survey had a low response rate despite efforts on the part of the author - only 16 students responded from University of Helsinki and 5 from University of Jyväskylä. It is acknowledged that respondents might differ from non-respondents but unfortunately it was not possible to find out how many students or alumni the surveys were sent to as they were sent out by the universities, and they could not provide exact numbers. However, it is likely that the maximum possible pool of student respondents for Surveys 1 and 2 would have been less than 50 for each university. The findings of Survey 3 , conducted by the university one year earlier, were included to expand the data. In addition, as the alumni were already in the workforce it provided a useful viewpoint regarding the usefulness of the course. 
The respondents in the different groups were asked to reflect upon their family background, motivations, perceptions about a career in development, and attitudes regarding different types of development cooperation. The responses were coded under themes, and general trends identified under each survey question, and where clear directions could be identified, they were discussed. In the interviews, general questions were used to guide the interviewee to discuss their life history and reflect on their experiences, and opinion regarding the successes and failures of development. It was also coded, identifying themes of interest.

The data were treated in an exploratory way, investigating the question of the motivations and expectations of students, and seeing which themes arose. From the research data we explore the students' motivations at the start of their studies and how they change during the course, and then once they are in working life (particularly if they begin work in development). The discussion also refers back to earlier research on the older cohort of development workers, without an academic background in development studies (White, 2015), and to entry level development practitioners in Junior Professional Officer posts (White, 2011; White et al., 2011).

\section{Findings}

The findings from the student survey data are summarised in Table 1 (the survey of the alumni only touched on some issues related to their working life and their opinions on the course).

\section{Motivations to start studies and current motivation}

The surveys began by considering motivations to study development.

\begin{tabular}{|c|c|c|}
\hline & $\begin{array}{c}\text { Survey } 1 \text { (Bachelor and Master' } \\
\text { students) }\end{array}$ & Survey 2 (Master's students) \\
\hline Respondents & 16 & 5 \\
\hline Gender & 4 men, 12 women & 1 man, 4 women \\
\hline Family background & $\begin{array}{l}\text { 13/16 had one or both parents } \\
\text { Finnish (and with citizenship of } \\
\text { upper or middle income } \\
\text { countries) }\end{array}$ & $\begin{array}{l}\text { Only } 2 / 5 \text { with Finnish parents } \\
\text { (three had citizenship of upper or } \\
\text { middle income countries) }\end{array}$ \\
\hline $\begin{array}{l}\text { Family experience } \\
\text { in development }\end{array}$ & $\begin{array}{l}4 / 16 \text { had parents who had worked } \\
\text { in developing countries or } \\
\text { themes to some extent }\end{array}$ & $\begin{array}{l}2 / 5 \text { had parents with development } \\
\text { practice experience }\end{array}$ \\
\hline $\begin{array}{l}\text { Development work } \\
\text { experience }\end{array}$ & $\begin{array}{l}\text { 9/16 persons had development } \\
\text { experience (ranging from } 1 \\
\text { month }-3 \frac{1}{2} \text { years, an average of } \\
12 \text { months each) }\end{array}$ & $\begin{array}{l}\text { All } 5 \text { with earlier development } \\
\text { experience (ranging from } 3 \\
\text { months - } 10 \text { years, an average } 42 \\
\text { months each) }\end{array}$ \\
\hline
\end{tabular}

Table 1: Summary of student survey data. 
In Survey 1, the main motivation mentioned to begin studies in development was to broaden their understanding of development issues (eight students) with comments such as wanting to: 'understand the complex world of ours and learn about development and everything that surrounds it', or 'learn more about social realities of developing countries and broaden my own perspective'.

The second most common motivation mentioned was to gain skills and experience to enable them to find work in development cooperation (five students). Altruism was noted as a motivation by only four students in writing. For instance: 'to do something meaningful and something that would make the world a better place, not worse'.

Money or expectations of a glamourous lifestyle were not mentioned by any respondents. In fact one of the recent graduates noted in interview:

Money was definitely not a motivation. We were all prepared for a very small salary, working with NGOs, doing a lot of volunteer work so I don't think anyone of my student peers expected a high salary or fancy lifestyle. We weren't really looking at the big career in the UN ....

Those with less experience in developing countries (e.g. none or one month) were more critical of development cooperation, and gave more black and white answers to the question of whether development cooperation is useful for the local beneficiaries. However, others also were critical. In interview, one of the students (who had worked in development at various times during her studies) elaborated

I think every development studies student goes into the studies with the hope that we can do something to improve people's lives and battle the structural inequalities that exist. Many of us have a crisis of faith during our studies, and I am no different.

Another recent graduate (in interview) stated that her motivations had more or less stayed the same throughout -

I wanted a more equal world ... I wanted to 'do good' - I had a guilty conscience for being part of the rich minority. And also I had a curiosity. My motivations have stayed the same now - the curiosity and wish to make the world a better place. The reality checks during my work in developing countries haven't changed things much.

A family history in development was noticeable among some of the student respondents. This was not likely until recently among Finnish entrants to development, as Finland has a short history as a development donor, unlike in British, French and other countries with a colonial past or long involvement in development.

Among the Survey 1 group, 4 of the 16 reported that their parents had worked in developing countries or themes to some extent.

My father worked in development cooperation for some 35 years. He is of the first generation of Finns to work in bilateral development cooperation projects ... Perhaps the 
most important thing I have learned from him is curiosity, but also I may have unfortunately also inherited a great deal of cynicism.

Another other of the respondents in Survey 1, with a parent from Latin America, noted that this had provided an understanding of the inequalities in the world, and was part of the motivation for studying.

Within the Survey 2 group, two of the five had family links to development or developing countries. Both parents of one student had worked in development cooperation and missionary work. They felt that it was significant and they learned a lot, both from discussions and from joining their parent on field trips. It appears to have been a significant motivator for studying in the same field.

With the smaller group of Masters' students responding to Survey 2, none expressed altruistic motivations at all for starting their studies. Their main motivations were to build upon their 'understanding the theoretical and practical aspects of the discourse' and to improve their skills for future employment. However, they also had more field experience and presumably had understood more of the pros and cons of development activities.

One of the faculty respondents noted that in Jyväskylä (Survey 2), some students are very practical and bring experience from development work, while others come from another field altogether. Some consider the course a means to analyse their own experiences - much as the authors of this article. In many ways this is a good example of coproduction, as they are bringing back practice to research.

The motivations of all the types of students were complex, and cannot simply be boiled down to wanting to 'do good', however, they could be re-categorised in line with Watt and Richardson's concept of 'social utility', combining altruism and the desire to learn and very practically make a contribution to sustainable development. Extrinsic factors of salary or career were not voiced. The most common motivations were intrinsic: wanting to learn more about development, and to analyse their own experiences. In many cases they were stimulated by a family background in development work.

What do you expect to learn during your studies? What is the role of development cooperation courses?

The questions then moved on to practical issues such as curriculum.

Some students in Survey 1 were happy with the critical approach to development that is taught in development studies. Expectations included a wish to learn about the reasons that some countries are less developed, and what problems they face, as well as possible transitions and information about the 'already developed' countries:

How in many, many ways the world is biased in favour of developed countries and how can these structural inequalities be confronted. No answers, only more questions. A critical view of the world as we know it. 
However, there was also clear feedback from current students (Survey 1) that they wished more technical/vocational development subjects could be included, and more about what development actually entailed and how they could fit into the sector. This was also reflected by the faculty staff interviewed - it appeared that the faculty was emphasising critical theory while students expected more vocational guidance. Certainly the more practical courses offered fill up immediately.

I was hoping it might be a bit more technical. I did the project management and Logframe course already in the first year and liked it. But it was only a week. It would have been great to have something practical that lasted longer than 5 days!

Students from Survey 2 also had an expectation of a combination of theoretical and technical approaches, which they could use later in professional work:

I expected to learn more about development work, its theory and practices i.e. to gain the skills that I would need if I were to work in that field.

The Alumni survey (Survey 3) demonstrated that most were satisfied with the basis that development studies had provided, including both critical thinking skills, and more practical elements such as information gathering and writing.

Development Studies provides a solid foundation for work in the field by being multidisciplinary and encouraging critical thinking. Development issues are challenges as seen from the perspective of both donor countries and recipient countries.

However, the survey specifically asked respondents about ways to improve the courses, and this drew some recommendations. One mentioned 'I would have liked more practical fieldwork experience-sharing'. Another emphasised that there should be more practical content rather than theory. A third commented that they would like 'more answers to questions, rather than only critical questioning'. Several mentions were made of the need for more academic and careers guidance, as well as the need for more practical or participatory courses, or subjects on project management. One commented on the need for technical skills in working life and recommended that specialisations be developed to better prepare 'strong development professionals'. 'More grip on developing more practical research, which would have been useful in working life. Although the history and theories are important, a focus on specific themes or geographic regions courses would have been more interesting for me.'

So in summary - both student groups as well as the alumni expressed an interest in a broader range of subjects - including both theory and practical courses, and many were looking ahead to the skills needed for a possible future career in development. 


\section{Who benefits most from development cooperation?}

As a means to examine the opinions of the students - presumably shaped both by their studies and their work experience as well as other factors like family experience in development - we asked who benefits most from development cooperation?

Here there was a difference between the responses of the Survey groups. Survey 1 students were the most critical, with most reflecting a negative view in general, and considering that the development industry and staff benefitted most (six mentions), versus only three who considered that the intended beneficiaries would benefit.

In monetary terms probably the institutions that run the industry and the people within them. Also the nature of the work often entails that people/organisations need to constantly validate what they are doing. NGOs need to make themselves necessary, as do multilateral agencies.

One considered a broader definition of benefit, beyond only financial gain.

Financially very often the 'giver', I guess, and big companies and big states. But there are also things that are not measurable, for example knowledge and relationships between people. Those are things in which both parties in cooperation can benefit.

This minority view would link well to development studies and development cooperation supporting a broader view of global justice and sustainability, both at home and in other countries. This philosophy fits well with the ideals of long-term volunteering, but it also reminds us of Wilson (2006) and his proposal that professional development workers can learn together.

On the other hand, the students from Survey 2 felt the benefits of aid were more positive. Four felt that the benefits were spread equally, while the fifth noted

Money and knowledge do not come free of commitment, and investments would not occur if there was no return ... it is certain that the local beneficiaries are not the party that benefits the most out of the endeavour.

In summary, it appears from these findings that the younger student group, with less practical experience, were more critical of development funding though there was also some insightful understanding of more nuanced understanding of intangibles like relationship building. However, as noted earlier, the small numbers make comparison problematic.

\section{Should we continue development cooperation in any form?}

However, when asked whether development cooperation should continue, all students from both Surveys 1 and 2 considered that development cooperation funding should continue, despite some criticism. 
We should [continue] but development cooperation funding is a drop in a bucket ..., so we should take the same line ... also in other fields, such as international markets etc. Giving development cooperation funding is not enough, or it's not changing anything, unless the global economic structures change.

In fact some of the Master's students considered that development cooperation was important, but that it should be reshaped - moving away from the concept of a one way donation, to a shared endeavour to deal with global problems, closer to the SDG concept.

There are lots of countries that need the support that development cooperation can give. And in the end I believe, even though it's full of contradictions, development cooperation gives more than it takes. I also think it is kind of the responsibility of the rich countries to provide the possibility of development cooperation and aid for example in topics like climate change which is a question that affects everyone.

One built on the relational ideals of development cooperation.

Development cooperation is not a donation or gift from the so called global north, but an endeavour between peers. Therefore, everyone should be providing development cooperation funding at all times, through many different means. As long as we keep defining everything through economic criteria, we will be locked in a very limited loop of chance-find successes and mostly indirect, unsustainable benefits.

They also were quite pragmatic regarding different types of development modality, describing the advantages and disadvantages of NGOs, the UN, the World Bank and bilateral projects. 'Volunteers can only work for so long. Development work is long and you need patience. You will not achieve anything with short term workers. You need to build relationships.'

One of the recent graduates included in Survey 1 is working in bilateral cooperation for a consulting company and noted the advantages over her earlier volunteer and NGO work, which was more limiting. Receiving a salary and safe transport makes life safer and allows her to concentrate on the work. She also stressed that having a bigger budget, using it responsibly and providing necessary technical advice allows her project to really have an impact in local communities.

Despite the concerns that some expressed regarding development funding, all the students still considered it was worthwhile. They felt that significant global changes were needed to address inequality, but that it was important to act at all levels, and not only wait for higher level changes.

\section{Employment - now or in the future}

The surveys aimed to examine whether the students planned to continue working in the development sector - and whether the alumni had already done so.

All of the Survey 2 group, and the majority of the current students from Survey 1, expressed an interest in working in development cooperation, for NGOs, UN 
organisations, the World Bank or the Finnish Ministry for Foreign Affairs. Consequently, despite some students expressing concerns regarding development cooperation, they were not opposed to working in the field.

Half of the alumni respondents (Survey 3 ) are working in traditional development cooperation posts -22 out of 44 respondents. This ranged from work in the Finnish Ministry for Foreign Affairs or embassies, NGOs, consulting companies or UN organisations. Six were unemployed or retired and two were students. Three more are working in development studies faculties. Hence the majority were in developmentrelated work. It could be considered that this is an extremely high ratio - more so than in many other countries. However, this is not reflective of the entire Finnish development studies alumni population - completing the survey involved some element of self-selection. It does demonstrate that until budgetary cutbacks (over the last two years) there has been a reasonable employment market for graduates of development studies. Many alumni progressed to work in development cooperation via Finnishfunded Junior Professional Officer posts in bilateral projects or multilateral organisations (White et al., 2011). Finnish-funded UN Volunteers posts have also been a source of experience.

To summarise, surveyed students of development studies have the expectation of continuing with a career in the development sector, irrespective of their expressed motivations for entering the course, and their opinions of the utility of development funding. This expectation appears reinforced by the finding that over half of alumni that responded to the survey were working in foreign affairs or international development.

\section{Discussion}

The findings above regarding motivations and attitudes reflected some earlier research (White, 2015) that a broader and longer experience in the field, with both the good and bad elements of development, tends to change preconceptions. Experience appears to make people more pragmatic and accepting of different viewpoints, although for some it also increases cynicism. In this earlier study, it was noted that in general, the older development workers interviewed expressed more altruism than the younger generation, while younger respondents (as in the current study) had very mixed motivations for working in development.

The respondents' motivations for study in the field are closely tied to the social utility value of how it could be useful to society in the future; as well as the intrinsic reward of the interest they have in the subject, wanting to learn more about development, and to analyse their own experiences. They expressed less motivation by value of salary and social status; although they hoped for employment after graduation.

Interestingly, all the respondents from Surveys 1 and 2 considered that development cooperation funding should continue, despite their exposure to critical discourses on development at university (in particular, a focus on theoretical courses in University 
of Helsinki at least). This could be a reflection of their interest in gaining employment in the sector. But many commented that while it should continue, development cooperation alone would not change anything, without a more profound change in the global economic structure. The SDGs are one way to approach this - considering that there is a need to address development globally, rather than only focusing on the problems facing developing countries.

Both the earlier studies and the current data demonstrate the desires of students and alumni for theoretical grounding, but also practical skills for a career in international development cooperation. Denskus and Esser's (2015) concerns regarding development studies education included unease that spaces for critical reflection are abandoned in the increasing need for employability of graduates. They contend that universities are increasingly assuming the role of a supplier of readily trained human resources with relevant skill sets, rather than taking a position outside of the workplace to critique large scale development cooperation. However, the students and alumni surveyed in this article, stress the need for these 'vocational' skills, in order to give them a possibility for work in the field. We must consider how those young entrants can get a start, with increasing competition in a narrowing market. Even the long-term volunteer postings are becoming more competitive and professionalised, making entry more difficult. The recent evaluation of the Australian Volunteers for International Development programme (Office of Development Effectiveness 2014) found that the overwhelming majority of volunteers had significant professional experience, important for the major objective of capacity building in the partner organisation. de Jong (2011) noted that international NGOs that have traditionally emphasised altruistic motivations, now have donor-imposed requirements for narrow results-based management and measurable outputs - hence the new graduates do need these vocational skills. And if they are not moving into development work, what is their employment future? A logical alternative is to work in their home country for global sustainable development. However, this will still require some on-the-job skills.

The increasing professionalisation of the development field probably shapes the pool of people who enter it and their attitudes toward it. Professionalisation involves both instilling particular skills and attitudes, and creating barriers to entry for those who lack these skills or attitudes. In the data presented there was a difference between the older, more experienced students in Survey 2, and the younger students in Survey 1. The latter had more experience and pragmatism, but also a clear desire for vocational skills and socialisation that could help them progress to careers in development. There is also a clear self-selection difference - those enrolling in the Jyväskylä course (Survey 2) are selecting the more practical course with a clearer career path into development work.

In a blog in 2012, Carr wrote -

I am concerned by some recent conversations that suggest that development studies programs should be about what the practitioners/implementers/donors want and need. The 
logic here is one of professionalization: those seeking development studies degrees ostensibly want jobs, and therefore they should be trained to do the sorts of things that their future employers want them to do ... [however] development is a constantly evolving field ... a good development studies program must also teach its newly trained professionals how to bring the latest and best thinking on development subjects to their employers in a manner that is implementable ... you need people in the program with experience in both academia and in the world of implementation, and who speak the languages of both worlds ... The best training on the latest thinking is useless if the trained cannot actually make use of what they know once they are employed.

This closely reflects the views of the authors or the importance of blending theory and practice, and combining critical thinking with constructive ideas.

Currie-Alder's (2016, p. 6) description of development education moving from a focus on 'poor places abroad' to 'global interdependencies' fits well with the move to SDGs in 2015. Education is important in promoting sustainable development globally and achieving the SDGs, creating an understanding of the links between how we live our lives and the impact of our actions on our planet. To some degree there are overlaps between development studies and emerging 'sustainability studies', especially as many 'developing' countries are rapidly moving to middle income status - and therefore questions of sustainable development, rather than simply survival, gain more local attention.

What is the necessary knowledge and skill set for good development practice? Naturally there is no exact recipe for success, and some roles require more specific technical skills (engineering, medicine, etc.), while others suit generalists. Most donor agencies select technical staff mainly based on very specific professional criteria (education and years of technical experience in the field), rather than personal attributes. But in order to be successful, common to all types of posts is a need for a combination of theoretical knowledge, technical skills, administrative know-how and attitudinal factors, such as a willingness to learn from others and share - 'learning from and building on local knowledge and strengths' (Devereux, 2008). The Office of Development Effectiveness (2014) evaluation noted that partner organisations identified the attributes of successful volunteers as 'flexibility, adaptability, patience, proactivity, openness and openmindedness, and enthusiasm' - critical attributes for all studying or working in development. Naturally it could be said that these attributes are relevant for all professions - but for those working in a different culture, in a potentially challenging environment, they are particularly important. In addition, in order to achieve the SDGs, practitioners in all countries need to be able to link policy and theoretical targets with the practice on the ground.

Probably the ideal basis for development work is critical thinking skills and development theory, as well as trust and openness to build good relationships with local communities, organisations and individuals, so as not to repeat the mistakes of the past, and to learn from what has worked. Optimism is important, and an openness and humility to finding a new way - including learning from others. These attributes are important both at home and abroad, and whether addressing national and international development 
goals as reflected in the new universal SDGs. Baillie Smith and Laurie (2011) list attributes and goals of volunteers, growing from and feeding back into development paradigms, including - benevolence and service, technical assistance/knowledge transfer, mutual learning, citizenship and empowerment, professional development, global citizenship, social justice, personal development and community building/strengthening (p. 549). We consider that these goals are important for anyone working in development.

One of the surveyed students (Survey 2) succinctly tied together his studies and the link to the SDGs

It was a very natural step from my studies and my professional experience ... I believe that multi-party, global cooperation will be of essence to respect the social justice thresholds of basic human development requirements, while staying below the sustainable development ceilings of environmental limits. This balancing act is a dire reality for new economic policies, and the common ground from which we will need to build our capacities. That is why I am studying this particular subject.

Melber (2014) discussed the evolution of development studies in light of changes in development practice itself -

Development studies has shifted its focus from seeking formulas and recipes to understanding local processes, with the intention of 'developing' people's ability to analyse the underlying social ... structures and the reproduction of hierarchies, both locally as well as globally, to contribute to the transformation of such structures towards more justice and equality through participation. (pp. 1091-1092)

He argues for a more radical and transformative role for development studies. In the move to the SDGs, development studies could play an important role in educating and working for a more equitable and sustainable world. Meanwhile Cochrane and Thornton (2017) argue for the role of development studies in ensuring nobody is left behind - the message of the SDGs.

Mobjork (2010) found that transdisciplinarity, combining the experience of practitioners and researchers could be a means to address complexity. As noted above, Baillie-Smith (2013) highlights the importance of 'co-production of critical academic knowledges' between practice and research. He finds that there is an increasing divide between the increasingly de-politicised development industry and mainstream development scholarship on the one hand, and political aspects of development education on the other. The findings tend to support this, with many of the students and alumni commenting on their wish for more practical skills and links to workplaces, but at the same time referring to a wish to tackle the structural causes of poverty and inequality (which seemed to be the basis for their interest in the whole topic of development studies).

At the same time, some in the research community have chosen not to engage in development practice, while others in the development industry complain that 
researchers are only criticising and not providing positive suggestions. Roper and Pettit (2002) claimed that most people work in development to change the status quo. While this may be overstating the case, there is, according to the findings of this article a genuine struggle of values and how best to do the work amongst students and practitioners. One of the interviewees, who had worked in roles with several different types of employer, noted the difficulty of open discussion of the problems of development, comparing it to other thorny issues like migration or racism.

It is so ideological that you can't have proper discussions about it and you feel like you have to defend it. That's the problem - it is so polarized. If you are within development, depending on what camp you are in, if you are consultant you have to defend yourself against the NGOs, and in the UN, likewise.

Hence, co-production might need more openness and willingness to combine the views of each side.

We need generalists who can work across disciplines, with a combination of theoretical knowledge, practical skills, administrative know-how, and very important attitudinal factors - willingness and openness to learn, sense of humour, humility, etc. Field work as a volunteer or Junior Expert provides a good basis, as do internships during studies. Returning to study after initial field experiences is another. Is there a chance to break down the silos, and work together more closely? A step in the right direction is via a direct engagement between academia and practitioners (both by bringing work experience back into full time studies, or managing studies concurrently with work). In this way practitioners receive a healthy dose of critical analysis, while students and researchers can benefit from practical experiences beyond a short research visit. White et al. (2011) found that 16 per cent of the surveyed Junior Professional Officers had returned to further academic studies in a related field to international development. And in the case of both of the authors of this article, we have returned to research following work as long-term development volunteers, as well as with the UN and consulting companies. As with others, we found that our practical experiences had ignited a wish to learn more and integrate our practical understandings and theoretical knowledge. This is another means to achieve co-production of academic knowledge, bringing back practical experience that can also stimulate deeper reflection and further learning in academic life.

\section{Conclusion}

This article does not offer solutions, but rather identifies some of the complexities, and a potential way forward to improve development studies.

It considered the motivations for studying and working in development via analysis of survey responses and interviews. Altruism was not the most important motivation for the younger student cohort - learning about the social realities of developing countries and broadening their perspectives were the main attraction. Gaining skills for 
employment was important for Master's level students, but also attracted some Bachelor's level students. All expressed a wish to find future work in development cooperation, and many wished for more vocational skills to help them in that goal in an increasingly professionalised business environment.

Some technical and professional roles in development require specific competencies (such as engineering and medicine). However, most development work needs generalists who are lateral thinkers and are able to cross disciplinary boundaries. Good development practice, including volunteering, research and technical cooperation, requires a combination of theoretical knowledge, technical skills, administrative know-how and attitudinal factors, such as a willingness to learn from others and build something new. This applies to volunteers and workers from all countries. Stereotypes of considering the ways development workers should think or act should be avoided, as there are many niches to fill. Considering the need to work together to achieve the SDGs at home and abroad, development studies faculties could work to develop this broader framework of capacities. Graduates may then be able to respond to a broader range of expectations. In addition to disciplinary knowledge, interdisciplinary knowledge of how to approach a problem in development and how to build reflective and reflexive attitudes and mindsets are also important competencies.

Can development studies and the development industry work more closely together, rather than in silos, to achieve the globally important SDGs? We find that co-production may be a way forward to overcome an excessively critical or vocational approach. This could then support inspired and sustained action by diverse actors (rather than burning out or leading to excessive cynicism); combining academic courses and research but also including reflective and experiential practice. Encouraging long-term volunteers and practitioners to return to study (either full time or alongside their practical work) and share their experiences is a good way to do this.

\section{Notes on contributors}

Ms Pamela White is a generalist, working with rural development, water supply, sanitation and hygiene (WASH) issues, and gender and human rights. She works with a consulting company in Finland (FCG International) and carries out short term consultancies globally. She is also working on a PhD in Development Studies with the University of Helsinki, focusing on the role and motivation of people working in development cooperation - as consultants, government, NGO and multilateral staff, researchers, and others.

Dr Peter Devereux is an adjunct research fellow at Curtin University's Sustainability Policy Institute. He is currently an Australian volunteer in Myanmar conducting research for AVI to assess the contribution of AVID Volunteers and their Myanmar hosts to the SDGs. Peter has focused on volunteering for development and sustainability policy, research and practice for over twenty five years. Previously he worked in United Nations Volunteers Headquarters; the School of Sustainability at Murdoch University; as lecturer and NGO environmental adviser in Nicaragua, UN volunteer in Fiji, and as manager of Australian Volunteer International's Perth office. 


\section{ORCID}

Pamela White (D) http://orcid.org/0000-0003-1659-5507

Peter Devereux (D) http://orcid.org/0000-0002-3003-3474

\section{References}

Akram-Lodhi, A. H., 2016. 'Introducing a virtual special issue: The state of development studies / Lancement d'un numéro spécial virtuel: l'état des études du développement', Canadian Journal of Development Studies / Revue canadienne d'études du développement, Vo. 37, No. 1, pp. 1-4, doi:10.1080/02255189.2016.1163157.

Baillie Smith, M. and N. Laurie, 2011, 'International volunteering and development: Global citizenship and neoliberal professionalisation today', Transactions of the Institute of British Geographers, Vol. 36, No. 4, pp. 545-559.

Baillie Smith, M., 2013, 'The changing development landscape and new development paradigms: The end of development education or a chance to find its voice?' Opening address to the conference, Global Justice Through Global Citizenship: The Role of Global Education and Public Awareness, Brussels, 20 November, www.mattbailliesmith.com/ talks-and-lectures.html.

Brown, E. J., 2015. 'Understanding and engaging in development through international volunteering'. Journal of International Development, doi:10.1002/jid.3145.

Buch-Hansen, M. and L. Lauridsen, 2012, 'The past, present and future of development studies', Forum for Development Studies, Vol. 39, No. 3, pp. 293-300.

Carr, Edward, 2012, 'Blogpost', http://www.edwardrcarr.com/opentheechochamber/2012/06/ 03/development-studies-as-a-degree-in-translation/.

Cochrane, Logan and Alec Thornton, 2017, 'The geography of development studies: Leaving no one behind', Forum for Development Studies, doi:10.1080/08039410.2017.1345786.

Corbridge, Stuart, 2007, 'The (im)possibility of development studies', Economy and Society, Vol. 36, No. 2, pp. 179-211.

Currie-Alder, B., 2016, 'The state of development studies: Origins, evolution and prospects', Canadian Journal of Development Studies, Vol. 37, No. 1, pp. 5-26.

de Jong, Sara, 2011, False binaries: Altruism and selfishness in NGO work, in Anne-Meike Fechter and Heather Hindman, eds, Inside the Everyday Lives of Development Workers: The Challenges and Futures of Aidland, Sterling, VA: Kumarian Press, pp. 21-40.

Denskus, T. and D. Esser, 2015, 'Countering the risks of vocationalisation in master's programmes in international development', Learning and Teaching, Vol. 8, No. 2, pp. 72-85.

Devereux, P., 2008, 'International volunteering for development and sustainability: Outdated paternalism or a radical response to globalisation?', Development in Practice, Vol. 18, No. 3, pp. 357-370.

Devereux, P., 2010, International Volunteers: Cheap Help or Transformational Solidarity Toward Sustainable Development, PhD: 407, Perth: School of Sustainability, Murdoch University.

Eyben, R., 2012, 'Fellow travellers in development', Third World Quarterly, Vol. 33, No. 8, pp. $1405-1421$.

Eyben, R., 2014, International Aid and the Making of a Better World, Oxon: Routledge. 192 pp. Fechter, Anne-Meike, 2011, 'Anybody at home? The inhabitants of Aidland', in Anne-Meike Fechter and Heather Hindman, eds, Inside the Everyday Lives of Development Workers: The Challenges and Futures of Aidland, Sterling, VA: Kumarian Press, pp. 131-149. 
Fechter, A.-M., 2012, 'Living well' while 'doing good' (missing) debates on altruism and professionalism in aid work', Third World Quarterly, Vol. 33, No. 8, pp. 1475-1491.

Fees, A. and S. Gray, 2011, 'Fast-tracking expatriate development: The unique learning environments of international volunteer placements', The International Journal of Human Resource Management, Vol. 22, No. 3, pp. 530-552.

Haddock, M. and P. Devereux, 2015, 'Documenting the contribution of volunteering to the SDGs: The challenges and opportunities of universal SDGs for IVCOs and volunteer groups', Forum Discussion Paper 2015.

Holdsworth, C., 2010, 'Why volunteer? Understanding motivations for student Volunteering', British Journal of Educational Studies, Vol. 58, No. 4, pp. 421-437.

Jones, A., 2008, 'The rise of global work'. Transactions of the Institute for British Geographers, Vol. 33, No. 1, pp. 12-26.

Melber, Henning, 2014, 'Whose world? Development, civil society, development studies and (not only) scholar activists', Third World Quarterly, Vol. 35, No. 6, pp. 1082-1097.

Mobjork, M., 2010, 'Consulting versus participatory transdisciplinarity: A refined classification of transdisciplinary research', Futures, Vol. 42, pp. 866-873.

OECD/DAC, 2010, Development Co-operation Directorate Statistical Reporting Directive 40, Development Assistance Committee, DCD/DAC (2010)40/REV1, pp. 15-17.

Office of Development Effectiveness, 2014, Evaluation of the Australian Volunteers for International Development (AVID) Program, Canberra: Department of Foreign Affairs and Trade.

Roper, L. and J. Pettit, 2002, 'Development and the learning organisation: An introduction', Development in Practice, Vol. 12, No. 3-4, pp. 258-271.

Simpson, Barbara, 2015, 'Large classes in social work education: A threat to the professional socialisation of social work students?' Social Work/Maatskaplike Werk, Vol. 50, No. 4, pp. 565-576.

Stirrat, R. L., 2008, 'Mercenaries, missionaries and misfits: Representations of development personnel', Critique of Anthropology, Vol. 28, No. 4, pp. 406-425.

Watt, H. and P. Richardson, 2008, 'Motivations, perceptions, and aspirations concerning teaching as a career for different types of beginning teachers', Learning and Instruction, Vol. 18, pp. 408-428.

White, P., 2011, Junior Professionals in Finnish Development Cooperation, Paper presented at the conference Reframing Sustainability? Climate Change and North-South Dynamics, Helsinki University, 10-11 November, unpublished manuscript.

White, P., Suoheimo, M., Ahonen, P., 2011, Evaluation of the Junior Professional Officer Programme of Finland, 2011:5, Jyväskylä: Ministry for Foreign Affairs of Finland, Kopijyvä Oy, 117 p., ISBN 978-951-724-966-9.

White, P., 2015, 'The spectrum of motivations, experiences and attitudes in technical development cooperation', Forum for Development Studies, Vol. 42, No. 1, pp. 89-112.

Woolcock, M., 2007, 'Higher education, policy schools, and development studies: what should master's degree students be taught?' Journal of International Development, Vol. 19, pp. 55-73.

Wilson, G., 2006, 'Beyond the technocrat? The professional expert in development practice', Development and Change, Vol. 37, No. 3, pp. 501-523.

Wilson, G., 2007, 'Knowledge, innovation and re-inventing technical assistance for development', Progress in Development Studies, Vol. 7, No. 3, pp. 183-199. 